\title{
Development of Individualism in Chinese Legislation and Social Solidarity - A Durkheimian Approach
}

\author{
By Helen Peng Han
}

\begin{abstract}
The concept of individualism plays an important role in Durkheim's work of sociology. He viewed the rise of individualism as an indicator to reflect a society's development. When a society develops, collective consciousness leaves more room to the development of individualism. Durkheim also argues that when society evolves, the predominance of different types of social solidarity changes. Durkheim developed his theory of using law as an external index to observe the changes of society. This paper applies Durkheim's approach in Chinese society and through examining the changes of individualism in Chinese legislation it concludes that individualism develops rapidly in Chinese society, reflected by the increasing focus on individuals and more protection of individual rights in both repressive and restitutive laws. This paper also argues that to avoid the occurrence of anomie, when individualism develops, more proper rules and laws should be developed accordingly.
\end{abstract}

Keywords: Individualism; Legislation; Durkheim; Solidarity; China

\section{Introduction}

Durkheim identified the fact that when societies become more advanced, there is less individual resemblance, shown by the historical biological evidence that the more differences in individual cranial capacity, the more advanced civilisation there is. Individualism, from Durkheim's view, refers to "personality", i.e. "the combination of the expression of individualized wants and needs and of beliefs, sentiments and ideas that derive from the individual's interaction with the social world." "Individuals are born different naturally in terms of the body, but there is change from the sacred body of individuals to the sacred personality in modern society. Personal autonomy unites individuals morally in modern society as it is the society which confines the scope of individual freedom. Although Spencer and the classical economists school argued that "the purpose of society, it is held, is the individual and for the sole reason that he is all that there is that is real in society...it adds nothing and can add nothing to this wealth of all kinds that the society stores up and that the individual benefits from", the existence of a society should mean more than that.

\footnotetext{
* LL.B; M.Jur; Ph.D. of law. Senior Lecturer, Department of Accountancy, Lingnan University, Hong Kong. Email: helenhan@ln.edu.hk.

${ }^{1}$ Cotterrell (1999) at 113-114.

${ }^{2}$ Durkheim (1950/1992) at 52.
} 


\section{Durkheim's View of Individualism}

According to Durkheim, society should have higher goals, not just a product to realise utilitarian interests. When moral values such as sympathy, respect, and kindness are eroded, there will be no correct moral restrictions on people, who may become greedy, and their desires can never be satisfied. Anxiety, dissatisfaction, pursuit of material desire, excessive production of anarchy, inequality, exploitation, and social conflicts day after day, ultimately endangering society as a whole. ${ }^{3}$ Morality needs to be rebuilt, argued by Durkheim, and the source of reconstruction is not a solipsism, but a sympathy for all people, a love for those who suffer, a greater enthusiasm to fight for them, reducing suffering, and achieving more justice. ${ }^{4}$ Durkheim has much confidence in the capacity of society to create morality, and moral morbid phenomena will eventually disappear. When morality is deeply rooted in the consciousness of each individual, moral individualism will become the "moral catechism" and the source of a new morality in modern society. At that time, the "cult of the individual" becomes one of the most distinctive characteristics of modernity and the individual and the society exist at the same time and complement each other.

Even though, as Cladis claimed, that Durkheim often talked of conflict between the individual and society in his works ${ }^{5}$ and he thought there was an antagonism between individual and society which mutually contradict and deny each other $^{6}$, for Durkheim, individuals cannot be separated from society. Individuals are "members" in a society, not only because of individuals' "subjective" role but also because only though society, can individual rights be regarded and private interests be gained. Durkheim has made a strong argument in this sense for disputing the postulate that the rights of the individual are inherent, admitting that the institution of these rights is in fact precisely the task of the state.

"History seems indeed to prove that the state was not created to prevent the individual from being disturbed in the exercise of his natural rights: no, this was not its role alone-rather, it is the state that creates and organises and makes a reality of these rights. And indeed, man is man only because he lives in society."7

That means that only through the state are individual rights possible. The state therefore plays an active and significant role in not only preventing individual rights from being obstructed but also providing necessary conditions for the realisation of individual rights. This is because it is the society which raises individual nature and "subject[s] that nature to itself." "Moreover, attitude toward morality in modern society, for Durkheim, is in fact "moral individualism", which is "a religion in which man is at once the worshiper and the god." 0 of course, such

\footnotetext{
${ }^{3}$ Tole (1993) at 16.

${ }^{4}$ Durkheim $(1898 / 1973)$ at 49.

${ }^{5}$ Cladis. (1992) at 115.

${ }^{6}$ See e.g. Durkheim $(1906 / 1974)$ at 59.

${ }^{7}$ Durkheim (1950/1992) at 60.

${ }^{8}$ Ibid.

${ }^{9}$ Durkheim (1898/1973) at 46.
} 
"sacred" dimension of modern individuality is not from some inherent rights of individuals. It is modern society which makes it possible in terms of granting rights and liberty to individuals and makes individuals themselves worshipful. For this reason, "every society is despotic" 10 because associations in society group individuals and exercise authority over their members by coercive measurement. However, such despotism of society is natural and necessary, because "the individual has been raised in this way by the collectivity, he will naturally desire what it desires and accept without difficulty the state of subjection to which he finds himself reduced." 11 "Moral individualism" is, in this sense, characterised by "(1) a set of social beliefs and practices that constitute a pervasive shared understanding or common faith that supports the rights and dignity of the individual; and (2) a plurality of social spheres that permits diversity and individual autonomy, and that furnishes beliefs and practices that morally associate individuals occupying a particular sphere." 12 Meanwhile, Durkheim believes in the productive function of the state in generating moral individuality as "it is the state that sets it [the moral individuality] free."13 "Far from its tyrannizing over the individual, it is the state that redeems the individual from the society [...] the fundamental duty of the state is laid down in this very fact - it is to persevere in calling the individual to a moral way of life."14 Therefore, for Durkheim, individualism is a "value system that emerges gradually as both a framework for and an expression of human nature in this sense" 15 as a balance between the force of the social sentiments and the individualised force of personal need. Individualism also ties individuals to society via the networks of responsibility to each other. $^{16}$

Individualism rises with the decline of the intensity of collective consciousness as there is a social fact that "the only collective sentiments that have become more intense are those which have for their object, not social affairs but the individual". ${ }^{17}$ Therefore, the individual personality must have gained more importance and "it is not enough for the personal conscience of each to have grown in absolute value, but also to have grown more than the common conscience [collective consciousness]."18

Durkheim advocates for Spencer's view that the place of the individual in society becomes greater with civilisation. He argues that the homogeneity of individual consciousness and collective consciousness is a characteristic of primitive society because the individual personality "did not exist"19 in primitive societies. Although he disagrees with Spencer's sociology concerning the causes

\footnotetext{
${ }^{10}$ Durkheim (1992). Bryan S. Turner (trans) Professional Ethics and Civic Morals, London: Routledge at 61 .

${ }^{11}$ Ibid.

${ }^{12}$ Cladis (1992) at 43.

${ }^{13}$ Durkheim (1950/1992) at 69.

${ }^{14}$ Ibid.

${ }^{15}$ Cotterrell (1999) at 114.

${ }^{16}$ Ibid. at 115.

${ }^{17}$ Durkheim (1893/1933) at 167.

${ }^{18}$ Ibid.

${ }^{19}$ Ibid. at 194.
} 
of the rise of individualism, he admits that "it is none the less true that individualism has developed in absolute value by penetrating into regions which originally were closed to it" 20 and it is "the fruit of an historical development". 21

Durkheim argues that the rise of individualism is a consequence of the development of division of labour and civilisation. He differentiates social division of labour from physiological one as in the former, an individual has freedom to change the role compared with cells in the organism. The fact is when there is more social division of labour, there is more flexibility and freedom in society. Individuals, therefore, are transformed while society changes as the number of social units and their relationships changes. Individuals free themselves increasingly from the dominance of the organism of society. The more development, growth and densely populated society, the more sociable humans become and psychological life developed as well. Individual personalities are formed and become conscious of individuals themselves and in turn the society becomes more complex and flexible. Hence, individualism is used by Durkheim as an indicator to reflect the social development and social transition.

\section{Durkheimian Approach: Law as Symbol of Social Solidarity}

As a pioneer of modern sociology, Durkheim published a large number of papers and monographs on education, religion, suicide, law, crime and so on, providing solid theoretical foundation for modern sociological studies. It should be also noted that among classical sociologists, he is also one of the founders of "legal sociology" or "socio-legal studies". Durkheim is assumed to provide an evolutionary theory on sociology and law. In his early works, he regarded the classification of law as a direct response to different types of social solidarities, which will be discussed particularly in later sections. In his later works, he emphasised that the law itself as a research field of sociology has important significance. He later found that the laws in modern society increasingly express a moral individualism and in this sense, individualism is the foundation of human rights which contains individual dignity and autonomy in nature. Such concept of individualism is different from selfishness and self-centeredness, which do not have moral basis. His many followers such as Marcel Mauss and Paul Fauconnet, also have outstanding contributions in the field of legal sociology.

In Durkheim's first major sociological work The Division of Labour in Society, he took social solidarity to be a central object of sociological analysis and accorded it a privileged place in his theoretical framework. This analytical concern came about because, for Durkheim, it is social solidarity which binds society together.

Durkheim shows his central concern with the changing nature of social solidarity and the function of the division of labour in society. He conceives the division of labour as the necessary condition of civilisation. While organic

\footnotetext{
${ }^{20}$ Ibid. at 198.

${ }^{21}$ Ibid. at 199.
} 
similarities can largely affect psychological similarities and then sensory impressions, the more individual resemblance in society, the more primitive the society is.

Durkheim also argues that the division of labour serves as the condition of the existence of societies, because "through it, or at least particularly through it, their cohesion would be assured; it would determine the essential traits of their Constitution" 22 , which is a much more important role than is ordinarily given consideration. It ensures the cohesion of societies because the true function of the division of labour is to create in two or more persons "a feeling of solidarity",23 and then it has developed to be the main cause of solidarity in society. Social solidarity arises where there are differences which require each other for their mutual fruition. Through the division of labour, individuals are linked to each other because they rely on one another in obtaining products that they cannot produce by themselves.

However, "social solidarity is a completely moral phenomenon which, taken by itself, does not lend itself to exact observation nor indeed to measurement." ${ }^{24}$ In order to examine to what extent social solidarity derived from the division of labour and "in what degree the solidarity that [the division of labour] produces contributes to the general integration of society [and] whether it is an essential factor of social cohesion" 25 , Durkheim proposed a strong argument that law is the visible symbol of social solidarity. This is because he found law as the "substitute" for social solidarity in the sense that law as "an external index which symbolises it [social solidarity] and [so we can] study the former in the light of the latter." Such substitution is possible because he conceives social solidarity as a moral phenomenon which can manifest its presence by sensible indices. Therefore, he categorises social solidarity by using its "visible symbol" - law. As juridical rules symbolise social solidarity, the categorisation of juridical rules corresponds to different types of social solidarity.

As "law reproduces the principal forms of social solidarity",26, Durkheim proceeds to find different types of social solidarity by classifying the different types of law. In order to categorise law scientifically, Durkheim identifies an essential characteristic to juridical rules, and thus, a different approach of the classification of law is developed. The characteristic is "sanction" as "every precept of law is a rule of sanctioned conduct." ${ }^{27}$ By classifying the different types of sanctions, it will be possible to find the different types of laws which correspond to them. ${ }^{28}$ There are two types of sanctions (and thus, as have been already noted, two classes of laws) - repressive sanctions and restitutive sanctions. Repressive sanctions consist of suffering and punishments, which are mainly contained in "repressive laws", such as criminal laws, and restitutive sanctions meaning the restore the status quo, are largely contained in "restitutive laws", such

\footnotetext{
${ }^{22}$ Ibid. at 63 .

${ }^{23}$ Ibid. at 56.

${ }^{24}$ Ibid. at 64 .

${ }^{25}$ Ibid. at 64 .

${ }^{26}$ Ibid. at 68 .

${ }^{27}$ Ibid. at 68-69.

${ }^{28}$ Ibid. at 49-70.
} 
as contract laws. For Durkheim, repressive laws comprise all penal law while civil law, commercial law, procedural law, administrative and constitutional law, after abstraction of the penal rules are restitutive laws.

Since law reproduces the principal forms of social solidarity, different types of solidarity which correspond to different types of laws are identified: mechanical solidarity and organic solidarity. The two terms are the key concepts that overarch the theoretical and empirical studies in Durkheim's research. The type of solidarity which corresponds to repressive laws is called "mechanical solidarity", which refers to a social solidarity that lies in the likeness of consciences in the population, wherein repressive measures are imposed, and which shows the extensive common morality. The type of solidarity which corresponds to restitutive laws is "organic solidarity", which concerns another source of social cohesion, i.e. the division of labour in society. In an organic solidarity society, individuals depend upon each other in terms of their differences from others and restitutive laws are prevalent.

In The Division of Labour in Society and in his subsequent essays and lectures, Durkheim used empirical evidence to show the progressive development of a society from a primitive one displaying mechanical solidarity as predominant to an advanced one where organic solidarity predominates owing to the increased division of labour in modern times.

For Durkheim, the two types of social solidarity coexist in different types of societies. Mechanical solidarity comes from social likenesses while organic solidarity emerges through the division of social labour. However, the predominance of the two types of solidarities varies in different types of societies.

In primitive societies ${ }^{29}$, mechanical solidarity is the predominant type. The individual is a part of the same collective type and shares common values or sentiments with others. Such shared common values or sentiments are called "collective consciousness", defined as "the totality of beliefs and sentiments common to the average citizens of the same society which forms a determinate system which has its own life." ${ }^{30}$ For example, the hatred of murder or rape can be a typical content of collective consciousness. As "society exists only by virtue of the reality of common values, ideas, and beliefs" 31 , collective consciousness constitutes the major source of social solidarity. Repressive laws largely exist in society as a measure of punishment of crimes which "offends strong and defined states of the collective conscience [collective consciousness]"32.

\footnotetext{
${ }^{29}$ It should be noted that in this essay, "primitive society" doesn't refer to the uncivilized society in barbarians but a concept used in Durkheim's theory which is characterized by mechanical solidarity, limited division of labour, the homogeneity of values, strong collective social bonds, little individualism, strong "collective consciousness" and repressive laws. Meanwhile, "advanced society" is used as a counter concept with "primitive society" where the division of labour is highly developed and is featured by the increased independence of social members from group, high "interdependence" between individuals, the rise of individualism, increasing secularism, tolerance, mutual indifference and weaker collective consciousness. I use these terms from Durkheim, but it should be emphasized that they are not to be understood pejoratively.

${ }^{30}$ Durkheim (1893/1933) at 79

${ }^{31}$ Hunt (1978) at 64.

${ }^{32}$ Durkheim (1893/1933) at 80.
} 
By contrast, in modern societies, through the development of the division of labour, the intensity of collective consciousness becomes weakened and individualism has increased because individuals rely more on others in the same measure that they are distinguished from them. The division of labour has developed and becomes the main cause of solidarity in society. The type of solidarity produced by the division of labour is organic solidarity, which developed to be the predominant type of solidarity in modern society. Restitutive laws have increased and performed a different function, compared with repressive laws: they restore the status quo. Contracts are the purest example of restitutive law. They are entirely grounded in the expectation that the other person will uphold their end of the contract.

Durkheim also discovered three pathological forms as the abnormal consequences of the development of division of labour during social transition. These are: anomie, enforced division of labour and the one lack of internal organisational coordination. Among those pathologies, anomie was suggested as an exceptional consequence of the division of labour when solidarity is not produced because "the relationships between the organs are not regulated." 33

Based on the above theory, this paper adopts Durkheim's approach of using law as an external index to observe the changes of society. As individualism is one of the key concerns of Durkheim, this paper selects it as research object and tries to observe the changes of individualism in the changing laws of the PRC in recent decades to understand the changing nature of social solidarity in China. Findings from Chinese laws and Chinese society will also reflect on the original Durkheimian theory.

\section{Changes of Individualism in Laws of China}

\section{Scope of Laws}

The data has been collected through in-depth selections of laws in China since 1982 until now. The reason for choosing 1982 as a starting point lies in the fact that Chinese legal infrastructure changed tremendously in that year after 1978 when China has launched open and reform regime. It was in 1982 when the constitutional framework of China was established on which the legal system is based.

For Durkheim, law is a coercive and regulatory force, which "reproduces the principal forms of social solidarity" 34 and "we can thus be certain of finding reflected in law all the essential varieties of social solidarity." 35 However, law, in Durkheim's analysis, is not explicitly defined. Nevertheless, "the implication is that law is the set of rules which are more or less formally promulgated and enforced in a society." 36 Thus, "law" in this paper refers to state law, which has

\footnotetext{
${ }^{33}$ Durkheim $(1893 / 1984)$ at 304.

${ }^{34}$ Durkheim $(1893 / 1933)$ at 68.

${ }^{35}$ Ibid. at 65 .

${ }^{36}$ Reiner (1984) at 177.
} 
universal validity backed up by state coercive power and is "more easily used to exemplify and measure the way in which social cohesion was created and changed in different types of society". 37

Thus, the research will analyse the changes of the state laws of the PRC which refers to a set of laws made through formal process of legislation in the PRC which have formed an integral system. As discussed before, by classifying "sanction", Durkheim finds two types of laws in society: repressive laws and restitutive laws. For Durkheim, civil law, commercial law, procedural law, administrative and constitutional law, after the abstraction of the penal rules are restitutive laws. Criminal law is the main type of repressive law.

Admittedly, it is hard to review all legal rules enacted through official legislative processes, and only key state laws issued by the NPC (National People's Congress) and the SCNPC (Standing Committee of the NPC) rather than all levels of legal rules will be examined as it is impossible to review every change of each article of all laws during the past years. Therefore, the most important changes in those restitutive laws will be analysed, which may indicate the most significant changes in organic solidarity over the past decades in the PRC.

\section{Findings: Rise of Individualism in Repressive Laws}

\section{Augmentation of protecting Human Rights}

Human rights are fundamental rights of individuals and without sufficient protection of human rights, individualism cannot sustain. Criminal law is the safeguard to protect human rights, and therefore it is stricter and more effective compared with other laws. This safeguard is an irreplaceable guarantee and the most solid backing for individual rights. Without criminal law, the implementation of protecting individual rights and individualism cannot be fulfilled satisfactorily. Therefore, the increasing importance of protecting human rights attached by criminal law represents a dramatic progress because it mirrors the rise of modern spirit of laws in society.

The criminal protection of human rights centres on the exercise of power for punishment. This lies in the realisation of protecting human rights in terms of prohibitive rules stipulated by criminal law. As the application and enforcement of power to punish are lying on the state and judicial organs, their public power should be restricted consequently; otherwise the abuse or illegal exercise of it would infringe human rights. Therefore, the change of criminal laws in protecting human rights, on the one hand, is reflected by approaches to legalise more private rights or to use more humane treatment of criminals, perpetrators, victims, family members and so on; on the other hand, by limiting judiciary power such as the prohibition of torture to extort confessions, the observance of "legality" principle to apply laws according exactly to laws and the absolute interdiction of criminal analogy and so on. According to this rationale, in this section, following two aspects are found:

On the one hand, the establishment of momentous and historic principles on human rights to limit public power that may infringe human rights, which includes

\footnotetext{
${ }^{37}$ Cownie, Bradney \& Burton (2007) at 10.
} 
five principles. On the other hand, the protection of specific rights is also under discussion.

\section{(1) Principle of Legality}

The principle of legality, to put it in a simple way, means no punishment should be allowed without an explicit regulation in statutory laws. Judgments should be made according to criminal laws and no sanctions or punishment can be imposed to suspects without provisions regulating on his/her crimes. Feuerbach, in his criminal jurisprudence, proposed a doctrine that "there is no crime and hence there shall not be punishment if at the time no penal law existed." 38

The aim of 1979 Code was to mainly protect "people" and "public goods" and therefore it lacks of conception of "rights protection". Moreover, before 1990, the Principle of Legality was criticised often in academic circle, which were found as basic principles as cornerstones for modern criminal law and rights protective spirit in later times. In practice, a "Severe and Fast" principle to combat crimes was endorsed which signified the lack of human rights notion from the top of the state around 1970s until 1990s. The state functionaries were required to fight crime as severe as they can and as fast as they can. Regulations at that time compassed much content which reflect "severe and fast" ordinance. ${ }^{39}$ In order to complete the task, there was extremely limited time for handling a criminal case, and sometimes the defendant had no time to hire a lawyer to defend for him. Large numbers of cases may lack justice as a consequence in judicial practice.

A tremendous change occurred in 1997 when basic principles of criminal law were established, which signified the occurrence of human rights notion and the consideration on individualism. It signifies that in PRC Criminal Law, human rights protection begins to be taken as fundamental tenet. In 1979 Criminal Code of the PRC (1979 Code hereinafter), there was no such principle and the regulations were very general rather than concrete. Article 3 in 1997 Criminal Code of the PRC (1997 Code hereinafter) begins to stipulate that only acts that are explicitly defined as criminal acts in law, the offenders shall be convicted and punished in accordance with law; otherwise, they shall not be convicted or punished. Abolition of the system of analogy and the reaffirmation of the non-retroactivity of a heavier law principle and making provisions with respect to the concrete crimes and the statutory punishment for them easier to be applied and so on can reflect the request of legality principle. This indicates that the value orientation of PRC Criminal Law begins to change from the laterality of protecting social rights to attaching equal importance to the protection of social and human rights, which is an explicit symbol of social transition from mechanical solidarity focusing mainly on public interests and collective consciousness to individualism oriented organic solidarity taking considerations on private rights and human rights.

\footnotetext{
${ }^{38}$ See at Wikipedia (2019b).

${ }^{39}$ For example, On the Supplementary Regulation of the Limit of Time for Completing Criminal Cases (1984) was stipulated according to the "fast principle"; On the Supplementary Regulation of Punishing Smuggling Crimes (1988) and On the Supplementary Regulation of Punishing Embezzlement and Bribery Crimes/(1988) were made according to the "severe principle".
} 


\section{(2) Principle of Prohibiting Criminal Analogy}

The principle of prohibiting criminal analogy is a derivative principle from the principle of legality. It means that judicial organs should only judge offences according to specified regulations stipulated in specific provisions of criminal laws on this particular crime rather than adopting similar provisions on other crimes or in other laws. The "Prohibition of Analogy" is a significant rule for modern criminology. The abolishment of this rule in 1997 Code, therefore, became a crucial and momentous signal to reflect tremendous progress in modifications of PRC criminal laws in terms of protecting human rights.

\section{(3) Prohibition of Ex Post Facto Laws}

"Ex post facto laws" is "a law that retroactively changes the legal consequences (or status) of actions that were committed, or relationships that existed, before the enactment of the law...it may aggravate a crime by bringing it into a more severe category than it was in when it was committed; it may change the punishment prescribed for a crime, as by adding new penalties or extending sentences; or it may alter the rules of evidence in order to make conviction for a crime likelier than it would have been when the deed was committed" 40 . The principle of prohibiting ex post facto laws derives also from the principle of legality, which means that actions that were committed legally before a new enactment of criminal law should not be criminalised or aggravated in its punishment. In "Decision on Severely Punishing Criminals Who Seriously Undermine the Economy (March 1982)" and "Decision on Severely Punishing Criminal Elements Seriously Endangering Public Security (September 1983)", the ex post facto laws was adopted, which has adverse effect on criminals and then abolished in 1997 Code. The thereafter criminal laws prohibited ex post facto laws completely which symbolise a leap in human rights protection in China.

\section{(4) Principle of Presumption of Innocence}

The doctrine of presumption of innocence as a minimum modern human rights protection rule in both state laws and international conventions means anyone should be deemed as innocent before he or she was proved to be guilty according to effective and plenty evidences. The duty to prove innocence should not be assumed by defendants. This principle is advocated popularly in international world and stated by the United Nations as one of the minimum standards for constituting state statutory criminal laws. In 1979 Code, even though no explicit provisions advocating the opposite rule of presumption of guilt, in some words or phrases it used can show the implicit adoption of the rule. Hence, the deletion of those words shows a tremendous transition in substituting presumption of guilt by presumption of innocence. For example, Article 247 of 1997 Code uses "criminal suspects or defendants" to replace "confession" and Article 94 and it also deleted "criminals" for describing judicial functionaries.

The deletion of stated words reflecting the presumption of quilt in 1997 Code and the particular stipulation of the presumption of innocence in Article 12 of the modified the PRC Criminal Procedure Law in 1996 both indicate the replacement

\footnotetext{
${ }^{40}$ See Wikipedia. (2019a).
} 
of "presumption of guilt" by the rule of "presumption of innocence" in Chinese penal laws, which unavoidably an indicator of extraordinary evolvement of PRC criminal law.

\section{(5) Prohibition of Using Force to Extract Testimony from Witnesses}

The prohibition of illegal detentions and the extortion of confessions through torture were regulated in 1979 Code as a basic guarantee for the rights of suspects and defendants avoiding harms from the authority or judiciary power. However, the personal life and interest of the witnesses were not fully protected until the erection of Article 247 in 1997 Code. In Article 247, "judicial workers who extort a confession from criminal suspects or defendants by torture, or who use force to extract testimony from witnesses, are to be sentenced to three years or fewer in prison or put under criminal detention. Those causing injuries to others, physical disablements, or death, are to be convicted and severely punished according to Article 234 and Article 232 of this law." The establishment of this rule effectively banned the occurrence of extracting testimony from witnesses by force or violence in practice during that time.

\section{More Stress on Private Rights especially the Right to Property}

The protection of private rights reflects the escalating individualism in society. Since the protection of private rights and intensification of individualism are inseparable, the increasing protection of private rights of individuals can also be deemed to possess an elite position in our discussion.

The comparisons between 1979 and 1997 articles show several improvements in the development of protecting specific rights of the victim, the criminals and the family members of criminals. Even though not many changes occurred, they are notable.

In order to protect the victim's rights, no limitation on the period for prosecution were changed to be imposed if a victim puts forward accusation during a limitation period for prosecution. Moreover, the right of "special defines/ preventive justifiable defines" was created for victims to fight against severe violent crimes, which refers to the defines against an on-going assault, murder, robbery, rape, kidnap or any other crimes of violence that seriously endangers individual personal safety, and then causing injury or death to the perpetrator of the unlawful act will not trigger criminal responsibility. The regulation with respect to the right of special defines is beneficial to victims and promotes the social solidarity among citizens, as it also encourages people to help others when they are faced with serious danger.

The civil and political rights of "freedom of religious belief" was established in the 1997 Code in Article 251, which regulates that citizens enjoy the freedom of religious belief no matter it is "legitimate" or not. In previous 1979 Code, only "legitimate" freedom of religious belief was protected which left large room for the interference of public power who judges what religious belief is legitimate and what is not. That discretion in judicial organs may create unfair judgments on this issue and anomie occurred due to such lack of explicit regulation and legal 
protection. The basic political rights of citizens were not fully protected in 1970s and 1980s.

Last but not least, in Article 59, a new rule was erected that when all of the property of a criminal is confiscated, necessaries of life for the criminal and his dependent family members shall be left out. In other words, the criminal and his or her families' economic rights began to be protected. This change not only indicated the humanisation of carrying out confiscation penalty of criminal's property, but also limited the harm to the family members' rights.

\section{Humanisation}

\section{(1) Derogating Death Penalty}

Dramatic decrease in the application of the death penalty occurred when 1997 Code modified stipulations in this field. The major modifications include the exclusion of minor criminals less than 18 years old out of the subject scope in applying death penalty and cutting down the number of crimes punishable by death penalty from 71 before the promulgation of 1997 Code to 68 in the revised Code, while the amount of crimes in total had increased from 130 in 1979 Code to 413 in 1997 Code. Lots of articles have restricted the application of death penalty positing stricter conditions in order to limit the free discretion of judges.

The abolition of death penalty reached its second peak in Amendment VIII in 2011. On the one hand, the death penalty will not be given to a person attaining the age of 75 at the time of trial, unless he has caused the death of another person by especially cruel means ${ }^{41}$; on the other hand, the death penalty in 13 economic nonviolent crimes were abolished ${ }^{42}$. Amendment IX in 2015 also abolished death penalty in crimes of counterfeiting currencies and crowdfunding fraud. Moreover, there are stricter rules and procedures to approve death penalty stipulated by Amendment $\mathrm{IX}^{43}$. That reflects the importance of respecting and protecting human rights that the law has attached to, as another indicator for social transition from mechanical to organic solidarity argued by Durkheim.

\section{(2) Care for Disadvantaged Group}

Two important revisions have been made of 1997 Code in this area. One is concerning the modification of the scope of criminal responsibility committed by a minor between the age of 14 and 16. The Article 14 of 1979 Code stipulates that those minors should bear criminal responsibility for serious crimes such as homicide, hurting someone severely, arson, stealing habitually or other crimes seriously disturbing social order. However, in judicial practice, as there was no criterion for understanding "other crimes seriously disturbing social order", the obscure and indefinite regulation resulted in the lack of criminal justice due to inordinate free appreciation of the court. Therefore, Article 17 in 1997 Code modified the stipulation to confined eight crimes which the minors between 14 and 16 shall bear responsibility: serious injury or death of the person, rape, robbery,

\footnotetext{
${ }^{41}$ Article 49 of 1997 Code.

${ }^{42}$ Such as crime of smuggling cultural relics, the crime of smuggling precious metals, crime of smuggling precious animal or animal products and so on.

${ }^{43}$ Article 50 of 1997 Code.
} 
drug-trafficking, arson, explosion or poisoning. This as a consequence makes the rule concrete and clear. The 1997 Code also abolished the Death Penalty with a two-year suspension of execution of juveniles between 16 and 18 in Article 49. These changes mirror the incarnation of individualised criminal punishment and the modern spirit of criminology in protecting the young criminals' legal rights with humanism.

Special treatment to disadvantaged group developed from amendment VI. Article 262 in Amendment VI created a new crime that: "Where anyone organises any disabled person or any minor below the age of 14 by force or coercion to beg, he shall be sentenced to fixed-term imprisonment of not more than three years or detention, and shall be fined. If the circumstances are serious, he shall be sentenced to fixed-term imprisonment of not less than three years not more than seven years, and shall be fined." 44 Such newly established crime of organizing disabled person or minors below 14 indicated the particularly social care to the young avoiding from being utilised as working instrument to earn money.

In Amendment VIII, special protection to the old, the pregnant women and the young highlighted the humane character of it. Article 17 was supplemented by: "A person attaining the age of 75 may be given a lighter or mitigated penalty if he commits an intentional crime; or shall be given a lighter or mitigated penalty if he commits a negligent crime." penalty of the old more than 75 years old established in Article 49 is another example. Despite those, the protection of the minors under 18 as a recidivist in Article 65 as well as the exceptional care of disadvantaged group in terms of the probation opportunities during criminal detention or short-term imprisonment ${ }^{46}$ all reflect the tremendous progress in terms of humanistic care to disadvantaged group in society in recent years. Amendment IX also expanded the Abuse Crime subjects to include persons and unit in charge of guardianship and care duties to better protect human rights of children and elderly. It is a significant progress which has profound effect to deal with the child and elderly abuse cases by kindergartner and carers. Nevertheless, the relevant laws are still insufficient to better protect the rights of disadvantaged group and need to be further improved.

\section{(3) More Opportunities to Minor Crime Offenders}

Article 68 of 1997 Code expanded the scope of mitigated punishment or exemption opportunities in order to encourage meritorious service. Compared with Article 63 of 1979 Code, the new rule separated the meritorious service from voluntarily surrenders' activities to obtain its own mitigation rules and the scope of meritorious services is largely expanded to encourage criminals to make contributions to society with result in lightening or exemption of their own punishments. Similar changes occurred in Amendment VII. Changes in Article 201 provided opportunities to enjoy mitigated punishment to tax payment criminals who have regretted. Amendment VIII also expanded the opportunities for criminals in terms of truthful confession in Article 67.

\footnotetext{
${ }^{44}$ See Amendment VI.

${ }^{45}$ See Amendment VIII.

${ }^{46}$ Article 72 is amended.
} 
One important issue to be mentioned here is the reporting obligation of the rehabilitated offenders. In 1979 Code, no such reporting obligation was issued but the 1997 Code, under the economy-oriented policy, in order to protect the employer's interest such rule was created in Article 100 as a result of derogation of human rights protection of criminals. Amendment VIII modified the rule and encouraged minor crime committers who have much less social harm, to make a fresh new start in society. This modification also prevents anomie that may arise leading to the retaliation upon the society by released person after the completion of criminal sentence.

\section{(4) Means or Methods for Criminal Treatment}

The deletion of shooting method in carrying out death penalty in 1997 Code shows a process of humanisation in the treatment of criminals, which also a basic requirement for human rights protection in modern world. Moreover, the inauguration of "community correction" as a supplementing means of "control (管制)" is an innovative method in punishment enforcement. ${ }^{47}$ "Community correction" perfects the implementation of judgments and laws, which means that when criminals were sentenced to the "control" as their sanction, they are no longer directly executed by the public security organs but to be exposed to the community correction under the supervision of communities and the public. Only in case of violation of certain special rules, the public security organs shall involve for further punishment. It is the embodiment of the socialisation and humanisation of punishment execution. Even though it also performs criminal penalty function, the severity is far lower than other means such as death penalty and imprisonment.

\section{Stress More on Property}

Among all private rights, the right to property is particularly imperative and essential. In Durkheim's work, it can most represent the evolution of laws and therefore, it is singled out as a consequence.

First, private property, no matter "lawful" or not, becomes legally protected in the tasks of the 1997 Code. Even though there is only one-word modification, namely, to use "the citizen's privately-owned property" to replace "the citizen's privately-owned lawful property", the protecting effectiveness and consequence can make a huge difference in practice. This is because if an authority bureau or judicial organ intends to intervene or do harm to some private property of a citizen, the previous article can provide the power with an excuse of exploiting individual property rights by desperately pointing out that their property is "unlawful" and the judgments of whether such property is lawful or not fall into the hands of authority and the power. Therefore, the modification of Article 2 in 1997 Code, in practice, resulted in a huge leap in private property rights protection in China.

Furthermore, 1997 Code also changed the scope of private property in its definition by expanding it to include "any means of production that are under individual or family ownership according to law; legal property owned by

\footnotetext{
${ }^{47}$ The original paragraph 2 is changed into paragraph 3 and amended as: "Criminals sentenced to control shall be subject to community correction."
} 
individual household and private enterprises; and shares, stocks, bonds and other property owned by individuals according to law" 48 which emerged due to the market development in that period. Moreover, the stipulations of 1997 Code added "property" as the targeted protecting objects in several places. It was added in the protected benefits in the rule of legitimised urgent danger prevention in Article 21, which shows the change in terms of the protection of "property" of both public and individuals in society because the rule encouraged the heroic performance to protect the public property or other's private property as a consequence. It shows that with the increasing protection of private property in repressive laws, the public property and public interest are also strengthened and protected more heavily. It was also particularly regulated in protecting the property rights of the criminals and their families, the creditors of the criminals and the victims and so on ${ }^{49}$.

\section{Findings: Changes of Individualism in Restitutive Laws}

Restitutive laws cover a large scope of constitutional and administrative Laws, Civil, Commercial and Economic Laws, Social Laws, Procedural Laws etc. Due to word limit, I only provide examples to indicate the overall changes.

\section{Administrative Laws: More Focus on Human Rights and Citizens' Rights}

The "organisational"-"remedy"-"procedural" process of Chinese administrative law indicates the expansion of citizens' rights: from being managed or governed by the administrative agencies to being authorized with the right of litigation and right to get remedy and finally to possessing a right of supervising and overseeing the performance of administrative organs. During this process, there is an increasing power owned by citizens. Every enactment of administrative law indicates a difficult enlargement of the scope of citizens' rights and an exploitation of certain interests of some government authorities. Each administrative law is a compromise agreement among various powers of interest groups. Therefore, the enactment of the administrative law encountered many obstacles during legislative processes. The more limits to the power of administrative authorities, the stronger opposition is expressed by the government organs ${ }^{50}$. However, those obstacles indicate a hard-won victory of citizen's rights and the profound significance of the enactment of administrative laws. For example, the Administrative Punishment Law stipulates the process of hearing during legislative process. It is the first time when the hearing process is applied in China which has met with fierce opposition when the law was drafted. ${ }^{51}$ It can be deemed as a victory of establishing a democratic mechanism in the PRC legislative process and has tremendous influence on the following laws. It has been argued that the large number of administrative litigations in practice provides a necessary motivation for the

\footnotetext{
${ }^{48}$ Article 92 of 1997 Code.

${ }^{49}$ See Article 59, 60 and 64 of 1997 Code, compared with Article 55, 56 and 60 in 1979 Code respectively.

${ }^{50}$ See Qin (2018).

${ }^{51}$ Ibid.
} 
transition of China from "rule of men" to "rule of law." 52 Even stronger opposition took place when the Administrative Licensing Law was drafted because compared with punishment law, it has much more to do with various interests of authorities and interest groups.

Nevertheless, along with the evolution of administrative law, citizens' rights have been expanded from obtaining compensations passively to supervising activities of government officials actively. Such expanding process can be observed from the establishment of essential laws from the Administrative Litigation Law, Compensation Law to Administrative Punishment Law, Supervision Law, Review Law, Licensing Law and Compulsion Law. These all reflect the increasing respect of the private and public rights of people by the administrative authorities. It can be expected that along with the development of administrative law of remedy, supervision and procedure, more protection of citizens' rights will be provided. However, there is a long way to go for realizing a fuller protection of citizen's rights and a more effective supervision on the government performance by the public.

One of the hot issues which should be mentioned in recent years is the System of Re-Education Through Labour (RETL) - reflects the adverse impact of the lack of human rights protection in practice. RETL can be regarded as one of the methods to enforce administrative punishments. ${ }^{53}$ However, it infringes the rights and freedom of citizens. The regulations on the objects of the RETL and the procedure of implementing the RETL are very obscure, which provide too much discretionary power for the administrative organs. ${ }^{54}$ The overuse of administrative power causes tragedies in practice in terms of enforcing innocent citizens to receive RETL forcibly. ${ }^{55}$ The approval of abolishing the RETL system in the 18 th The Central Committee of the Communist Party of China in 2013, therefore, indicates a tremendous improvement in protecting citizens' human rights recently.

\section{Laws relating to Private Property Rights}

It has been claimed that property right is the foundation of individual liberty that citizens enjoy. ${ }^{56}$ The 30 -year PRC reform history reveals a process of the recognition, expansion and protection of property right. The concept of "Private Property Right" rises along with the deeper implementation of the reform and opening up policy and the development of the socialist market economy. This section argues that there is an improvement in the protection of private property right reflected by the content of rules in legislation and will only focus on the changes of laws stipulating rules regarding private property. As the regulations of private property are mainly stipulated in the Constitution, the 1986 General Principles of Civil Law (GPCL hereinafter), the Law of Succession, the Land Administration Law, the Guarantee Law, the Property Law, the Law of Rural

\footnotetext{
${ }^{52}$ Feng (2008). '

${ }^{53}$ Jun (2004) at 43.

${ }^{54}$ Chen (2001).

${ }^{55}$ Zhang (1999).

${ }^{56}$ Buchanan. (1993) at 59.
} 
Land contracts and the Criminal Law and so on, discussions will only be focused on these laws.

In the early 1980s, the only civil law which contained relevant rules on private property was the Law of Succession in $1985 .^{57}$ The first major development in protecting property right after 1982 was the enactment of the GPCL ${ }^{58}$ which provides that a citizen's lawful property shall be protected. ${ }^{59}$ However, the concept of "property right (物权)" was absent from the GPCL. Moreover, no equal protection for the property rights of the state, the collectives and individual citizens was declared by the GPCL. Instead, it provided unequal status for private property and state property in Article 75. Several key laws including The Land Administration Law (1986), the Administrative Urban Real Property Law (1994), the Guarantee Law (1995) and so on set out some rules regarding property rights. Even though they are "by no means well-organised, clear and tidy, the trend since the 1980s of giving increasing scope to private (as distinguished from statecontrolled) economic activities on land and to the private sector of the economy may be seen from the foregoing review of legislative and constitutional developments." 60 Those laws became the major sources for drafting the PRC Law of Property.

\section{(1) The Legislation of Property Law}

After being deliberated for 7 times, the Property Law was finally passed in $2007^{61}$. It refers to many issues which possess Chinese characteristics such as the property of the state-owned enterprises, rural land contract and management rights, and "ownership by owners of apartments in condominium buildings (建筑物区分所有权)”. Even though it has not revolutionized the existing law, its main significance lies in "providing a conceptual framework for the purpose of organizing, consolidating and systematizing the existing law relating to property rights in movable and immovable property." ${ }^{, 62}$ One of the most significant contributions lies in the declaration of equal protection for the property rights of the state, collectives and individuals. ${ }^{63}$ Even though it has been challenged that there is a big difference between the protection of public property and private property in practice ${ }^{64}$, the establishment of the "equal protection" principle has been regarded as a victory of the law drafters over the critics who challenged that the draft of Property Law was "unconstitutional". ${ }^{65}$ Such victory was viewed as a

\footnotetext{
${ }^{57}$ Article 3 of the Law of Succession (1985).

${ }^{58}$ Chen (2011).

${ }^{59}$ Article 75 of GPCL.

${ }^{60}$ Chen (2011).

${ }^{61}$ For the deliberation process of Property Law, see Liang (2010) at 65-69.

${ }^{62}$ Ibid.

${ }^{63}$ Article 3 (3) of the Property Law.

${ }^{64} \mathrm{Ma}(2008)$.

${ }^{65}$ In 2005, Prof.GONG Xiantian published a public letter named “一部违背宪法和背离社会主义
}

基本原则的物权法草案 [A Draft of Property Law Which Violates the Constitution and Socialist Basic Principles]" who argued that the draft of Property Law as "unconstitutional" 
major breakthrough in Chinese legal and political thinking. Therefore, the Law of Property has been deemed as a milestone which "is one of the most important core components of the evolving civil law in the PRC."

\section{(2) Marriage Laws}

Being influenced by the Soviet civil theory, the marriage relationship was treated as a special relationship which was excluded by the civil relationships and therefore, marriage law in China was legislated as an independent department for a long time. After the mid-1990s, scholars began to argue for a "return" of marriage law to be one of civil laws. From then on, marriage law changed from a law cantering on "the identity as family members (亲属身份法)" towards a law focusing on “the property right of families (亲属财产法)". An increasing number of rules regulating the property right have been stipulated in amendments. For example, when marriage law was amended in 2001, much more detailed rules were stipulated regarding the division of property when a marriage is ended. ${ }^{67}$ Moreover, a no-fault party shall have the right to make a request for damage compensation under some circumstances when bringing about divorce. ${ }^{68}$ Those changes in the modification of marriage law reflect an increasing attention paid to property right by Chinese marriage law.

\section{(3) Company Law}

When the Company Law was established, according to the principle of “decision by Capital Majority (资本多数决定)”, the large shareholders had more discourse power and there was a lack of recognition of the protection of the interests of small shareholders. ${ }^{69}$ When it was modified in 1999, 2004, 2005 and 2013 continuously, various rules were established in order to put more emphasis on the protection of the rights and interests of small shareholders. Those rules include “the right to know (知情权)”, “the appraisal right (回购请求权)”, “the proceedings against the Board resolution (对公司决议的诉讼)” which reflect the more protection of individual rights. Moreover, the 2013 amendment simplified the setup rules of a company and abolished some key requirements for the company establishment, including the paid-in capital, the minimum of registered capital, the instalment of registered capital contribution and the capital verification in order to encourage the development of the individual private economy. ${ }^{70}$

because it declared of equal protection for the property rights of the State, Collectives and private persons. See Liang (2010) at 67.

${ }^{66} \mathrm{Ibid}$. at $\mathrm{p} 81$.

${ }^{67} 9^{\text {th }}$ SCNPC. Decision Regarding the Amendment of Marriage Law of the PRC, passed on April $28,2001$.

${ }^{68}$ No. 30 of the Decision Regarding the Amendment of Marriage Law of the PRC.

${ }^{69}$ Zhao (2009).

${ }^{70}$ Article 7, 23, 26, 27, 29, 33, 59, 77, 81, 84, and 157 were modified. 


\section{(4) Securities Law}

In the 1990s, the rapid development of the Chinese securities market and the lack of supervision by regulators led to an increasing number of civil disputes caused by insider trading in listed companies, false statement, and the manipulation of the stock market et cetera. However, before 2001, the lawsuits of those types were all dismissed by the PRC courts, which failed to protect the right of individual investors. The SPC announced "Some Provisions of the SPC on Trying Cases of Civil Compensation Arising from False Statement in Securities Market/关于审理证券市场因虚假陈述引发的民事赔偿案件的若干规定” in 2003 in order to regulate the civil acts in the securities market and protect the legitimate rights and interests of investors. It made an influential impact on the judicial trials on cases concerning securities compensation in practice. The modified the Securities Law clarified the civil liability regime and built the confidence of individual investors to invest on Chinese securities market. Even though there is still a lack of advanced system in practice, the development of Securities Law demonstrates the increasing protection of the rights and interests of individual citizens by legislators.

\section{(5) Bankruptcy Law: The Priority of Workers to Claim Compensation}

Besides the creditors, employers are the victims of the bankruptcy of a corporation, whose interests are directly harmed. However, in the old bankruptcy legal system of China, their rights were not fully protected. Therefore, the Bankruptcy Law (2006) provided a privileged place for workers to claim compensation when a corporation was bankrupted in Article 132. This reflects the increasing respect and protection of workers' rights in Chinese bankruptcy law. Moreover, it shows the increasing importance that the law attaches to the individual rights of labour in modern China.

\section{More Protection of the Interests of Migrant Workers}

The PRC labour migration from agriculture to non-agricultural sectors and from rural to urban areas is regarded as an inevitable trend in the process of industrialisation and urbanisation. ${ }^{71}$ The graph below shows the rapid increase in the number of rural migrant workers in Chinese urban area over decades. It is difficult for a rural migrant with rural "household registration (户口)" to obtain an urban household registration permanently. This leads to the fact that rural migrants are excluded from accessing most urban welfare services, health care and educational services. Generally speaking, they cannot get fully access to workrelated injury insurance, medical insurance, unemployment insurance, endowment insurance, subsistence allowance and cannot enjoy sufficient public welfare or community welfare.

\footnotetext{
${ }^{71}$ Qiu (2018).
} 
Figure 1. The Number of Rural Migrant Workers in China ${ }^{72}$

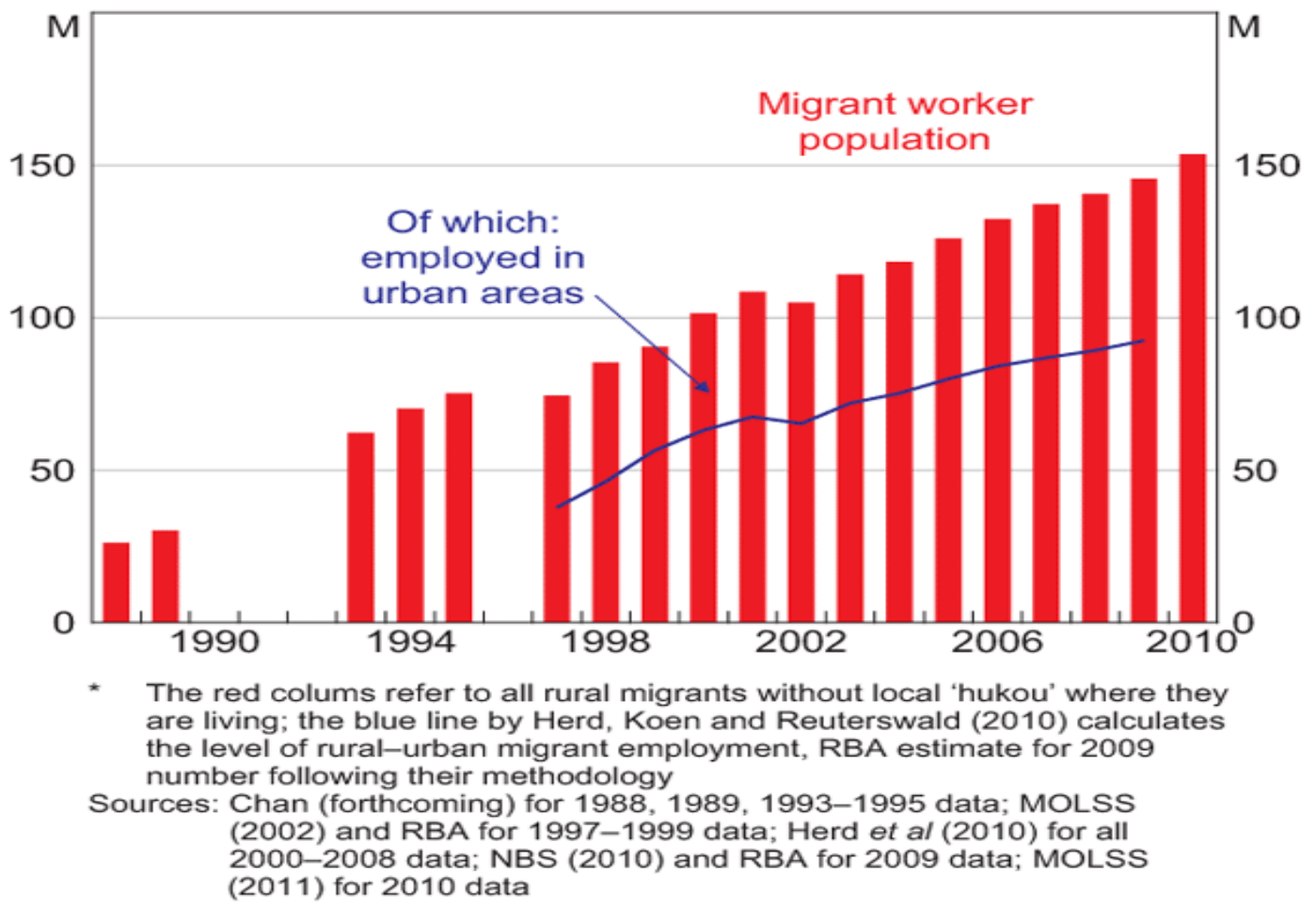

As discussed previously, with regard to the issue of protecting the rights of rural migrant workers, laws and regulations were enacted gradually. The Labour Law stipulates strict rules in wage payment; ${ }^{73}$ the Law on Labour Contracts provides specific regulations to ensure the access of labour compensation; ${ }^{74}$ The Law on the Promotion of Employment also provides important rules for protecting the rights of rural migrant workers. However, in practice, a number of employers ignore those laws and even though they sign labour contracts with rural migrant workers, contract fraud may frequently occur as a means for the exploitation of labour. In order to facilitate the enforcement of labour laws, various regulations were issued by the central and local government in order to provide more protection for the rights of rural migrant workers in terms of improving their social security and working environment. These regulations include the Notice on Making a Good Job in Employment and Management Services for Migrant Workers (2003), the Notice on Solving the Problems of Arrears for Migrant Rural Workers' Wages by Construction Enterprises (2003), the Regulation on Labour Security Supervision (2004), the Notice by the Ministry of Construction on the Opinions of Further Solutions to the Problems of Arrears of Project Funds in Constructions (2004), the Interim Procedures on Settlement of Cost of Engineering Construction (2005) etc. In 2006, the State Council also issued the Opinions of the State Council on Addressing Migrant Worker Issues. To enforce these laws and regulations, local regulations were made which had effective influence in practice.

\footnotetext{
${ }^{72}$ Rush (2011).

${ }^{73}$ Article 50 of the PRC Labour Law.

${ }^{74}$ Article 30 of the PRC Labour Contract Law. See also Article 10(1), 17(6), 85.
} 
According to the General Labour Union, 30.13 billion yuan (RMB) wage arrears were paid to rural migrant workers in total. ${ }^{75}$

\section{Conclusion}

Individualism develops rapidly in Chinese society, reflected by the increasing focus on individuals and more protection of individual rights in both repressive and restitutive laws. Collective consciousness allows more room for the growth of individualism in society when society develops. Meanwhile, the increasing individualism during social transition reflects the changes in the nature of social solidarity from mechanical to organic.

However, it should be noted that the rapid increase of individualism might also cause certain problems. If individualism develops too rapidly in society, anomie may occur, which derives from the tension between individualism and collective consciousness. As rules deriving from the division of labour are necessities for building solidarity, if such rules are not be developed in accordance with the speed of the development of the division of labour or they are vague and loose, or they lack of effective implementation, an abnormal form occurs. This is named anomie because the division of labour does not produce solidarity when the relations of the organs are not regulated. Therefore, this anomie caused by "the lack of regulation". When anomie occurs, social problems may appear, which may affect social stability and order. Therefore, to avoid the occurrence of anomie, when individualism develops, more proper mechanisms and rules should be developed accordingly.

Nevertheless, it can be seen that the current Chinese society is experiencing a good trend of development, reflected by the development of Chinese laws. It is expected that the status of individualism will become higher in society in the future, indicating increasing growth of organic solidarity in Chinese society.

\section{References}

Buchanan, J.M. (1993). Property as a Guarantor of Liberty. Cheltenham: Edward Elgar Publication.

Chen, A.H.Y. (2011). 'The Law of Property and the Evolving System of Property Rights in China', in Guanghua Yu (ed.) The Development of the Chinese Legal System-Change and Challenges, 82. London and New York: Routledge.

Chen, X. (2001). 'RETL: Analysis According to International Human Rights Convention' in FAXUE [Legal Science] 10: 49-52.

China Daily.(2017). ‘总工会：5年为农民工追回被拖欠工资301.3亿元[General Labour Union: 30.13 billion yuan (RMB) wage arrears were paid to rural migrant workers in recent 5 years]. http://paper.people.com.cn/rmrb/html/2017-09/26/nw.D110000renm rb_20170926_7-04.htm

\footnotetext{
${ }^{75}$ China Daily (2017).
} 
Cladis, M.S. (1992). A Communitarian Defense of Liberalism - Emile Durkheim and Contemporary Social Theory. Stanford: Stanford University Press.

Cotterrell, R. (1999). Émile Durkheim: Law in a Moral Domain. Edinburgh: Edinburgh University Press.

Cownie, F., Bradney, A. \& M. Burton. (2007). English Legal System in Context. 4th ed. Oxford: Oxford University Press.

Durkheim, É. (1893/1933). The Division of Labour in Society. George Simpson (trans). New York: Free Press.

Durkheim, É. (1893/1984). The Division of Labour in Society. W.D. Halls (trans) London: The Macmillan Press.

Durkheim, É. (1898/1973). 'Individualism and the intellectuals', in Robert N. Bellah (ed.) Emile Durkheim: On Morality and Society, 49. Chicago: University of Chicago Press, pp. 43-57.

Durkheim, É. (1906/1974). 'The Determination of Moral Facts', in D.F. Pocock (trans) Sociology and Philosophy, 59. New York: Free Press.

Durkheim, É. (1950/1992). Professional Ethics and Civic Morals. Bryan S. Turner Cornelia Brookfield (trans). London: Routledge.

Feng, J. (2008). 'China Administrative Rule of Law 30 years', in Rule of Law in China 1978-2008, 181. Beijing: Social Sciences Academic Press.

Hunt, A. (1978). The Sociological Movement in Law. London: Macmillan Press.

Jun, L. (2004). 'On the Principle of Proportionality in Administrative Law'. Thesis of Master's Degree, Xiang Tan University.

Liang, H. (2010). Comments on China's Civil Legislation. Beijing: Law Press.

Ma，G. (2008). ‘中国财产权法律保护三十年回顾 ['30-year Review of the Legal Protection of Chinese Property Rights]’, in Ma L. 30-year Rule of Law: Review, Reconsideration and Prospect, 齐鲁法学文库 [Qilu Law Collections], 135. Beijing: China People's Public Security University Press.

Qin, X. (2018). Interview of YING Songnian: '30-year PRC Administrative Legislation: Difficulty in Enacting the Administrative Procedure Law and the Administrative Charging Law'. Available at http://news.sina.com.cn/c/2013-11-01/015428587349. shtml

Qiu, H. (2018). 'Opening Speech at the China-Canada Workshop on Improving the Conditions for Migrant Workers in China'. At http://english.mofcom.gov.cn/aarticle /translatorsgarden/famousspeech/200806/20080605605843.html

Reiner, R. (1984). 'Crime, Law and Deviance: the Durkheim Legacy', in Steve Fenton, Durkheim and Modern Sociology, 177. Cambridge, N.Y.: Cambridge University Press.

Rush, A. (2011). 'China's Labour Market' in Bulletin: September Quarter 2011

Tole, L.A. (1993). 'Durkheim on religion and moral community in modernity' in Sociological Inquiry 63(1): 1-29.

Wikipedia. (2019a). 'Ex post facto law', Available at http://en.wikipedia.org/wiki/Ex_ post_facto_law.

Wikipedia. (2019b). 'Paul Johann Anselm Ritter von Feuerbach'. Available at http://en.wi kipedia.org/wiki/Paul_Johann_Anselm_Ritter_von_Feuerbach.

Zhang, P. (1999). 'Some Thoughts on Problem of Pre-Implementing RETL' in 犯罪与改造研究 [Crime and Rehabilitation Research] 2: 21-22. 